\title{
Minireview \\ Neoadjuvant endocrine therapy in primary breast cancer: indications and use as a research tool
}

\author{
YH Chia', MJ Ellis ${ }^{1,2}$ and CX Ma*,1,2 \\ 'Department of Medicine, Division of Oncology, Washington University, 660 South Euclid Avenue, St Louis, MO 63I I0, USA; ${ }^{2}$ Siteman Cancer Center, \\ Washington University, 660 South Euclid Avenue, St Louis, MO 63110, USA
}

Neoadjuvant endocrine therapy has been increasingly employed in clinical practice to improve surgical options for postmenopausal women with bulky hormone receptor-positive breast cancer. Recent studies indicate that tumour response in this setting may predict long-term outcome of patients on adjuvant endocrine therapy, which argues for its broader application in treating hormone receptorpositive disease. From the research perspective, neoadjuvant endocrine therapy provides a unique opportunity for studies of endocrine responsiveness and the development of novel therapeutic agents.

British Journal of Cancer (2010) I 03, 759-764. doi:10.1038/sj.bjc.6605845 www.bjcancer.com

Published online 10 August 2010

(c) 2010 Cancer Research UK

Keywords: breast cancer; oestrogen receptor; neoadjuvant endocrine therapy; genomics; relapse risk

For patients with locally advanced breast cancer, neoadjuvant chemotherapy is commonly recommended to improve surgical outcomes. However, for postmenopausal women with oestrogen receptor (ER)-positive disease, endocrine treatment is a logical alternative because of its established efficacy in the adjuvant setting (EBCTCG, 2005) and the increasing recognition that chemotherapy may be less effective in ER + HER2- disease (Berry et al, 2006; Hayes et al, 2007). Historically, neoadjuvant endocrine therapy was reserved for older and frail patients with ER + breast cancer. However, recent studies of this treatment modality in younger and healthier postmenopausal women showed that the improved surgical outcomes and response observed with the endocrine approach do not show an interaction with age (Olson et al, 2009), justifying the increased acceptance of neoadjuvant endocrine therapy in younger postmenopausal women with better performance status. For premenopausal women, neoadjuvant endocrine therapy remains investigational. In this review, we will present results of the major neoadjuvant aromatase inhibitor (AI) trials and discuss recent progress in using neoadjuvant endocrine therapy as a research tool to assess endocrine responsiveness and evaluate novel therapeutic interventions.

\section{NEOADJUVANT ENDOCRINE THERAPY: THE CLINICAL DATA}

The potential benefit of endocrine therapy in the neoadjuvant setting was initially suggested in earlier studies of tamoxifen, as a primary treatment approach for elderly women with breast cancer who were too frail to undergo other forms of therapy such as surgery (Preece et al, 1982; Horobin et al, 1991; Bergman et al, 1995).

*Correspondence: Dr CX Ma; E-mail: cma@dom.wustl.edu Received 18 March 2010; revised 24 June 20 I0; accepted 19 July 20 I0; published online 10 August 2010
The clinical response rate was in the range of $30 \%$ and higher, with long-lasting responses observed in some of these patients (Preece et al, 1982; Bergman et al, 1995). Subsequent randomised trials of tamoxifen $v s$ surgery followed by tamoxifen conducted in elderly women with operable breast cancer showed that surgery is essential for optimal local control, but tamoxifen alone achieved a similar overall survival compared with surgery followed by tamoxifen (Willsher et al, 1997; Mustacchi et al, 2003; Hind et al, 2006; Chakrabarti et al, 2010). These investigations laid the foundation for the design of subsequent studies of AIs in younger and healthier postmenopausal women with bulky hormone receptor (HR)-positive disease to achieve better surgery outcome. The letrozole P024 trial (Eiermann et al, 2001), the Immediate Preoperative Anastrozole, Tamoxifen or Combined with Tamoxifen (IMPACT) trial (Smith et al, 2005) and the Preoperative 'Arimidex' Compared to Tamoxifen (PROACT) trial (Cataliotti et al, 2006) were three of these studies (Table 1).

In the P024 trial, letrozole treatment was associated with a statistically significant improvement in the rate of breast conservation compared with tamoxifen. The anastrozole-based IMPACT and PROACT trials also showed a trend favouring the AI arm, although the results in comparison with tamoxifen were not statistically significant (Smith et al, 2005; Cataliotti et al, 2006). A meta-analysis of these trials supported the notion that an AI was more effective than tamoxifen for promoting breast conservation (Seo et al, 2009). A promising 76\% rate of breast conservation was also observed in a single arm phase II study of neoadjuvant exemestane in postmenopausal patients with $\mathrm{HR}+$ tumours $3 \mathrm{~cm}$ or greater after 12 weeks of therapy (Mlineritsch et al, 2008). The American College of Surgeons Oncology Group has recently completed accrual to the randomised phase III Z1031 trial to determine whether there are any differences in efficacy between the three approved AIs in this setting (NCT00698971). Preliminary data from this trial indicate that there are no clinically significant differences between these agents as neoadjuvant treatment (Ellis et al, 2010). 
Table I Summary of the letrozole P024, IMPACT and PROACT trials

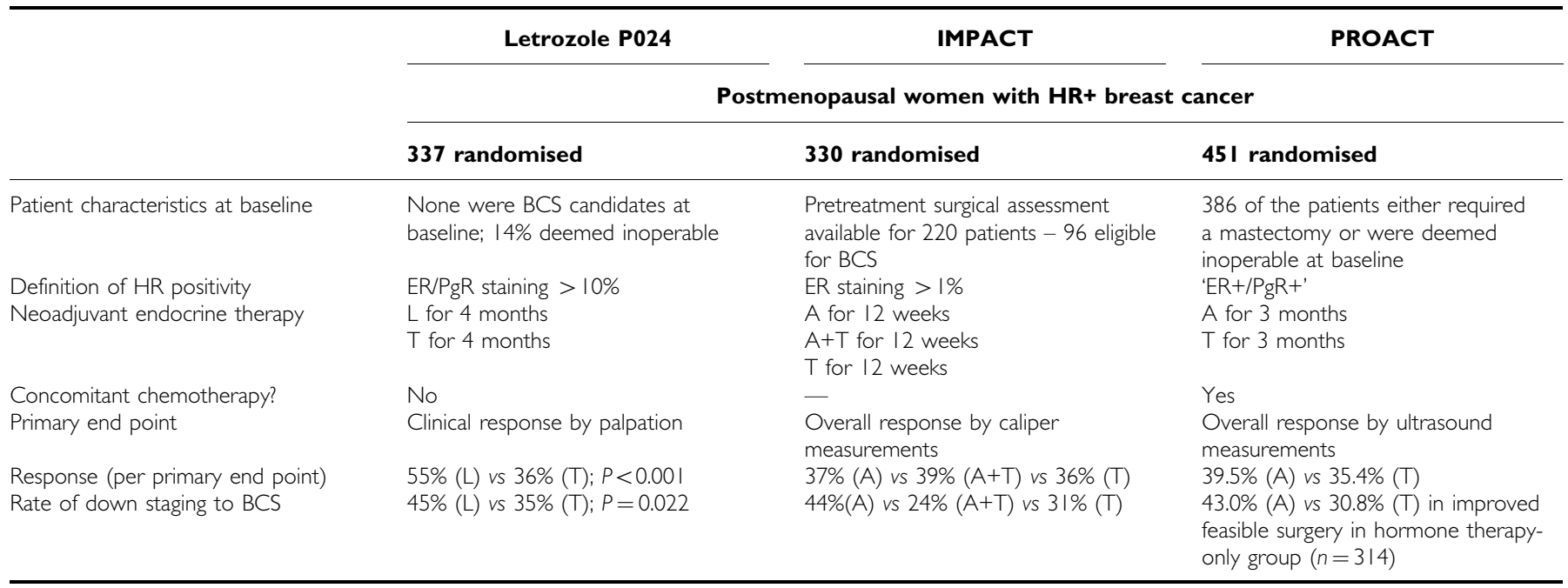

Abbreviations: $A=$ anastrozole I $\mathrm{mg}$ daily; $\mathrm{BCS}=$ breast conserving surgery; $\mathrm{ER}=$ oestrogen receptor; $\mathrm{HR}=$ hormone receptor; $\mathrm{IMPACT}=\mathrm{Immediate}$ Preoperative Anastrozole, Tamoxifen or Combined with Tamoxifen; $L=$ letrozole $2.5 \mathrm{mg}$ daily; PROACT = Preoperative 'Arimidex' Compared to Tamoxifen; PgR = progesterone receptor; $\mathrm{T}=$ tamoxifen $20 \mathrm{mg}$ daily.

\section{PREOPERATIVE ENDOCRINE THERAPY IN PREMENOPAUSAL WOMEN}

In an early study by Gazet et al (2001), 13 premenopausal women with ER + breast cancer received neoadjuvant goserelin, a gonadotropin-releasing hormone $(\mathrm{GnRH})$ analogue. At 3 months, seven of the 13 women had an overall response by clinical assessment, suggesting that premenopausal women may also benefit from neoadjuvant endocrine manipulation (Gazet et al, 2001). Torrisi et al (2007) investigated the use of letrozole and a $\mathrm{GnRH}$ analogue as primary therapy in premenopausal women with $\mathrm{ER}+$ breast cancer. These patients received a GnRH analogue for a median of 5.2 months and letrozole for a median of 4 months. In the 32 evaluable patients, one achieved a pathological complete response (pCR) and 15 obtained a clinical and imaging partial response (Torrisi et al, 2007). These studies suggest that neoadjuvant endocrine therapy is effective in selected premenopausal women with ER + breast cancer and further study in this patient population is needed.

\section{COMPARISON WITH PREOPERATIVE CHEMOTHERAPY}

A direct comparison between neoadjuvant chemotherapy and endocrine therapy was reported by Semiglazov et al (2007), in which 239 postmenopausal women with untreated invasive breast cancers that were ER and/or progesterone (PgR) positive received either combination chemotherapy with doxorubicin and paclitaxel every 3 weeks for four cycles $(n=118)$ or AI treatment with either exemestane $(n=60)$ or anastrozole $(n=61)$ for 3 months (Semiglazov et al, 2007). The clinical overall response, rates of pCR and disease progression did not differ significantly among the groups. The breast conservation rate was slightly higher in the AI groups at $33 \%$ compared with $24 \%$ in the chemotherapy arm. These findings support the hypothesis that AI therapy is an appropriate low toxicity neoadjuvant approach, but a definitive randomised study that compares neoadjuvant endocrine therapy to chemotherapy has yet to be reported. Ideally, a trial that compares the two approaches would take a predictive model forward into the clinical trial design, as subpopulations of breast cancer may benefit more from chemotherapy, while others from endocrine manipulation (van de Vijver et al, 2002; Paik et al, 2004; Parker et al, 2009).

More recently, the GEICAM cooperative group reported a randomised phase II trial of chemotherapy $v s$ exemestane in pre- and postmenopausal women (Alba et al, 2010). Ninety-five patients with localised $\mathrm{ER}+, \mathrm{PgR}+, \mathrm{HER} 2-$ and $\mathrm{CK} 8 / 18+$ (immunohistochemistry marker for luminal subtype) breast cancer were randomly assigned to chemotherapy (epirubicin plus cyclophosphamide every 3 weeks for four cycles followed by docetaxel every 3 weeks for four cycles) $(n=47)$ or exemestane (with goserelin if premenopausal) $(n=48)$. Tumour response was measured by magnetic resonance imaging. More than $50 \%$ of the participants were premenopausal women $(n=24$ in the chemotherapy arm and $n=27$ in the hormonal therapy arm). The response rate was higher for chemotherapy in the premenopausal patients ( 18 of the 24 in the chemotherapy arm $v s 12$ of the 27 in the hormonal therapy arm, $P=0.027)$, but in postmenopausal women and those with a low baseline Ki67, responses were comparable. The underperformance of exemestane and goserelin in premenopausal women may reflect the fact that this can be inadequate for endocrine therapy in some patients, with a failure to suppress ovarian function. Alternatively, primary endocrine therapy resistance is likely to be higher in a premenopausal population and a more accurate predictive model for endocrine therapy efficacy is needed.

\section{RECEPTOR STATUS AS SELECTION CRITERIA FOR NEOADJUVANT ENDOCRINE THERAPY}

Oestrogen receptor positivity remains the single most important criterion for eligibility for neoadjuvant endocrine therapy. Patients with an ER Allred score of 6 and above are the most likely to respond (Ellis et al, 2001). The data on PgR status does not support its use as a selection criterion in the context of ER positivity, and $\mathrm{PgR}+\mathrm{ER}-$ tumours are too uncommon to make a definitive statement with regard to their management (Ellis et al, 2001). HER2 status has been investigated in both the IMPACT and the P024 studies. Although the presence of HER2 amplification does not preclude a meaningful response to an $\mathrm{AI}$ in the neoadjuvant setting (Ellis et al, 2001; Smith et al, 2005), HER2 positivity is associated with a lower suppression of Ki67, a marker of cell proliferation, in response to either tamoxifen or letrozole (Ellis et al, 2006), 
suggesting treatment resistance to endocrine therapy alone. In practice, most patients with HER $2+$ tumours receive trastuzumab in combination with a chemotherapy regimen because of the high pCR rate. Although the combination of trastuzumab and an AI has shown promising results in patients with metastatic disease (Marcom et al, 2007; Kaufman et al, 2009), it has not been adequately tested in the neoadjuvant setting.

\section{PREDICTING LONG-TERM OUTCOMES AFTER NEOADJUVANT THERAPY}

Neoadjuvant chemotherapy studies have firmly established that response, and particularly $\mathrm{PCR}$, is a strong predictor of survival in breast cancer patients. However, in the subset of patients with ER+ HER2 - disease treated with chemotherapy, pCR has limited value, as these patients often do well despite the absence of pCR because of effective adjuvant endocrine therapy (Buchholz et al, 2001). Pathological CR is very uncommon in response to neoadjuvant endocrine therapy. In three relatively large studies with letrozole, the pCR rate was no more than 1\% (Eiermann et al, 2001; Baselga et al, 2009; Olson et al, 2009). Although residual cancer burden after neoadjuvant chemotherapy has been shown to predict distant relapse-free survival (Symmans et al, 2007), the application of this measure to patients who underwent neoadjuvant endocrine therapy remains to be evaluated. To identify alternative post-treatment factors that predict breast cancer survival after neoadjuvant endocrine therapy, Dowsett et al (2007) examined Ki67 expression before and after 2 weeks of endocrine therapy. Patients with higher Ki67 expression after 2 weeks of endocrine therapy had a significantly lower recurrence-free survival (Dowsett et al, 2007). In a multivariable analysis conducted on the P024 trial (Ellis et al, 2008a), four factors were determined to have independent prognostic value for relapse and death after relapse. These included pathological tumour size (T1/2 vs T3/4), pathological node status (positive or negative) and two biomarkers in the surgical resection specimen, the natural logarithm of the Ki67 value and the ER status of the tumour. A prognostic score, the preoperative endocrine prognostic index (PEPI), was developed, which weighs each of these factors according to their associated hazard ratios (Table 2). The PEPI was then validated in an independent dataset from the IMPACT trial (Ellis et al, 2008a). No relapses were recorded in either trial in patients with T1, N0 tumours with a PEPI score of 0 (residual tumour with Ki67 index of $2.7 \%$ - natural logarithm of 1 - or less with maintained ER expression) or in the rare patient with a pCR. These patients are not likely to benefit from adjuvant chemotherapy as endocrine therapy alone appears to adequately control their disease. These results supported an amendment to the Z1031 trial (Cohort B), in which chemotherapy was not recommended to patients in the pathological stage $1 / 0$ PEPI 0 category. The acceptability of this advice will be assessed to see if this approach can be made a protocol mandate in the next phase of clinical trial development. In addition, patients with a high Ki67 proliferation index in a 2- to 4 -week biopsy ( $>10 \%$ ) are triaged to neoadjuvant chemotherapy or immediate surgery, as these tumours are exhibiting primary endocrine therapy resistance (Dowsett et al, 2007). To determine the chemotherapy responsiveness of this group, the rate of pCR with neoadjuvant chemotherapy in the high ontreatment Ki67 group will be determined (Figure 1). If this approach to tailoring neoadjuvant endocrine therapy is feasible, a larger, more definitive study will be considered.

\section{GENOMICS TO DETERMINE THE MOLECULAR BASIS FOR THE VARIABLE RESPONSE TO ENDOCRINE THERAPY}

Discovery genomics is a complex process that often requires fresh-frozen material, an adequate sample size, patient consent to
Table 2 The PEPl

\begin{tabular}{|c|c|c|c|c|}
\hline \multirow[b]{2}{*}{ Pathology, biomarker status } & \multicolumn{2}{|c|}{ RFS } & \multicolumn{2}{|c|}{ BCSS } \\
\hline & HR & Points & HR & Points \\
\hline \multicolumn{5}{|l|}{ Tumour size } \\
\hline $\mathrm{TI} / 2$ & - & 0 & - & 0 \\
\hline $\mathrm{T} 3 / 4$ & 2.8 & 3 & 4.4 & 3 \\
\hline \multicolumn{5}{|l|}{ Node status } \\
\hline Negative & - & 0 & - & 0 \\
\hline Positive & 3.2 & 3 & 3.9 & 3 \\
\hline \multicolumn{5}{|l|}{ Ki67 level } \\
\hline $0-2.7 \%\left(0-1^{b}\right)$ & - & 0 & - & 0 \\
\hline$>2.7-7.3 \%\left(1-2^{b}\right)$ & 1.3 & । & 1.4 & । \\
\hline$>7.3-19.7 \%\left(2-3^{b}\right)$ & 1.7 & I & 2.0 & 2 \\
\hline$>19.7-53.1 \%\left(3-4^{b}\right)$ & 2.2 & 2 & 2.7 & 3 \\
\hline$>53.1 \%\left(>4^{b}\right)$ & 2.9 & 3 & 3.8 & 3 \\
\hline \multicolumn{5}{|l|}{ ER status, Allred score } \\
\hline $0-2$ & 2.8 & 3 & 7.0 & 3 \\
\hline $3-8$ & - & 0 & - & 0 \\
\hline
\end{tabular}

Abbreviations: $\mathrm{PEPI}=$ preoperative endocrine prognostic index; $\mathrm{RS}=$ relapse-free survival; $\mathrm{BCSS}=$ breast cancer-specific survival; $H R=$ hazard ratio; $E R=$ estrogen receptor. ${ }^{a}$ To obtain the PEPI score, risk points for RFS and BCSS were assigned depending on the HR defined in the P024 analysis (Ellis et al, 2008a). The total PEPI score assigned to each patient is the sum of the risk points derived from the $\mathrm{PT}$ stage, pN stage, Ki67 level and ER status of the surgical specimen. An HR in the range of I -2 receives one risk point; an HR in the $2-2.5$ range, two risk points; an HR greater than 2.5 , three risk points. The total risk point score for each patient is the sum of all the risk points accumulated from the four factors in the model. For example, a patient with a TI N0 tumour, a Ki67 staining percentage of $1 \%$ and an ER Allred score of 6 will have no risk points assigned. In contrast, a patient with a T3 NI tumour, a Ki67 staining percentage of $25 \%$ and an ER Allred score of 2 will have a total relapse score of $3+3+2+3=11$. ${ }^{\text {b }}$ The natural logarithm interval corresponding to the per cent Ki67 values on the original percentage scale.

genetic studies and access to sophisticated analysis techniques. To date, the number of publications on genomic profiling in the context of neoadjuvant endocrine therapy remains few and the sample sizes are small. For example, Miller et al (2009) reported on a series of 52 patients, 37 were considered letrozole sensitive and 15 resistant. A predictive model was developed that used all three types of gene expression variable: baseline, on-treatment and change in treatment, to differentiate between the two groups. This paper illustrates the variety of bioinformatics approaches that can be taken when before and on-treatment paired samples are available for analysis (Miller et al, 2009). Other investigations are ongoing to assess the predictive value of established molecular signatures, such as the Netherlands Cancer Institute NKI 70 gene (van de Vijver et al, 2002), 21 gene recurrence score (Paik et al, 2004) or the PAM50 (Parker et al, 2009), performed on tumour samples taken after the initiation of endocrine therapy (Ellis et al, 2008b). The Z1031 trial has recently completed accrual of 375 patients, despite mandatory fresh tumour tissue acquisition, through the provision of tissue acquisition kits and the active collaboration of surgical investigators. Z1031 patients are also consented for massive parallel DNA sequencing to define complete cancer genomes (Ding et al, 2010). Very detailed information on the molecular characteristics of endocrine therapyresistant and -sensitive tumours is therefore a near-term prospect.

\section{NEOADJUVANT TRIALS TO GENERATE PROOF-OF-PRINCIPLE DATA FOR NOVEL ENDOCRINE THERAPY COMBINATIONS}

The superior efficacy of adjuvant aromatase inhibition $v s$ tamoxifen in reducing the risk of recurrence was mirrored by 


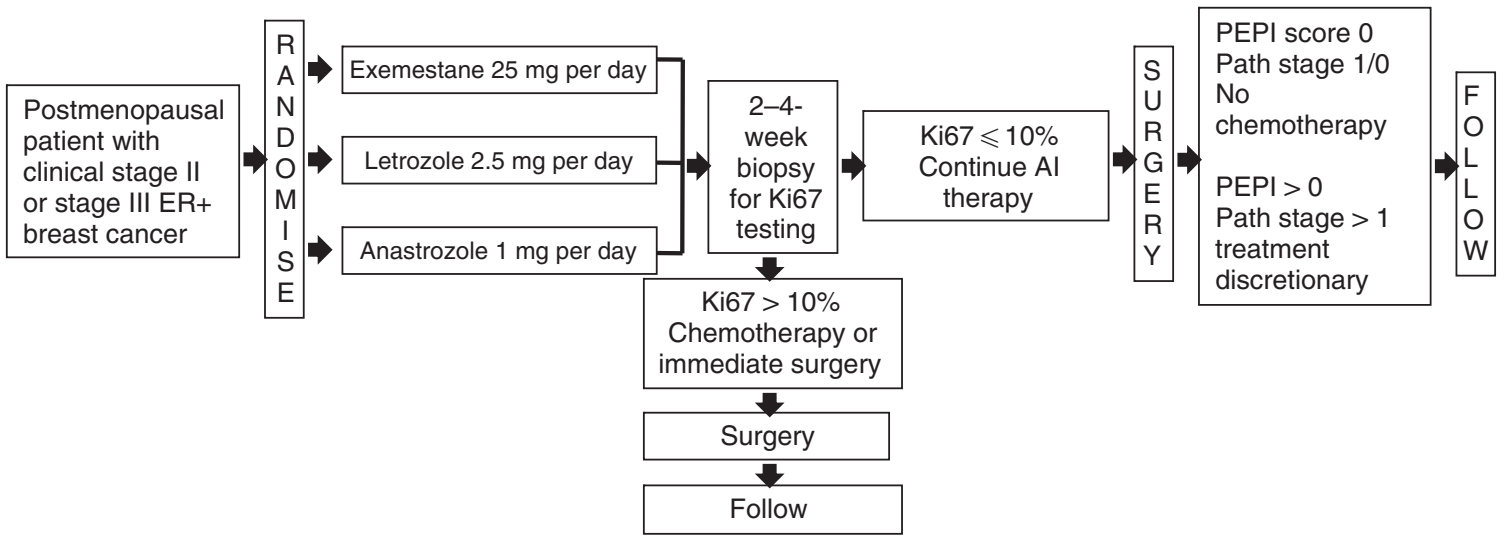

Figure I Schema for ACOSOG trial ZI03I Cohort B.

advantages for aromatase inhibition as neoadjuvant therapy. This was most consistently seen with letrozole, with both the clinically based (Eiermann et al, 2001) and Ki67-based data (Ellis et al, 2003) correctly predicting that letrozole would be the more effective adjuvant treatment (Thurlimann et al, 2005) several years in advance of the actual result. Anastrozole was also shown to be a superior antiproliferative agent in comparison with tamoxifen in the neoadjuvant setting, and the failure of the anastrozole/ tamoxifen combination arm to improve outcomes in the ATAC trial (Howell et al, 2005) was mirrored by the inferior antiproliferative response seen in the combination arm of the IMPACT trial in comparison with anastrozole monotherapy (Dowsett et al, 2005). These datasets provide strong arguments for the value of neoadjuvant endocrine therapy trials as a 'proving ground' to test the efficacy of new endocrine therapy approaches for breast cancer. Phase 2 randomised studies of endocrine therapy and signal-transduction inhibitor combinations have been recently reported for gefitinib and anastrozole (Polychronis et al, 2005; Smith et al, 2007), and the rapamycin analogue, RAD001, with letrozole (Baselga et al, 2009). The combination of anastrozole and gefitinib was not found to be superior to anastrozole alone. The combination of RAD001 and letrozole showed improved antiproliferative response and clinical response by palpation at the expense of more adverse events. Perhaps, the most convincing evidence for progress with a novel endocrine therapy combination would be an enhanced rate of PCR as evidence for the activation of a cell death process that would more effectively delete ER + breast cancer cells before the acquisition of resistance to endocrine therapy (Crowder et al, 2009) or an increased rate of PEPI score 0 following neoadjuvant therapy.

\section{REFERENCES}

Alba E, Calvo L, Albanell J, De la Haba J, Chacon J, Arcusa Lanza A, Sanchez Rovira P, Plazaola A, Lopez Garcia-Asenjo J, Lluch A, on behalf of GEICAM (2010) Chemotherapy (CT) versus hormone therapy (HT) as neoadjuvant treatment in luminal breast cancer: a multicenter, randomized phase II study (GEICAM/2006-03). J Clin Oncol 28, (Suppl) 7s (abstract 500)

Baselga J, Semiglazov V, van Dam P, Manikhas A, Bellet M, Mayordomo J, Campone M, Kubista E, Greil R, Bianchi G, Steinseifer J, Molloy B, Tokaji E, Gardner H, Phillips P, Stumm M, Lane HA, Dixon JM, Jonat W, Rugo HS (2009) Phase II randomized study of neoadjuvant everolimus plus letrozole compared with placebo plus letrozole in patients with estrogen receptor-positive breast cancer. J Clin Oncol 27: 2630-2637

Bergman L, van Dongen JA, van Ooijen B, van Leeuwen FE (1995) Should tamoxifen be a primary treatment choice for elderly breast cancer patients with locoregional disease? Breast Cancer Res Treat 34: 77-83

\section{CONCLUSIONS}

Neoadjuvant AI therapy is a clinically valuable, logical and increasingly accepted approach to neoadjuvant systemic therapy for postmenopausal women with ER + HER2 - breast cancer. With an array of new agents and predictive biomarkers to investigate, the time for further randomised trials to compare neoadjuvant endocrine treatment with conventional chemotherapy in a broad spectrum of patients with $\mathrm{ER}+$ breast cancer has probably passed - particularly if the trial under consideration is not prospectively testing a predictive biomarker for endocrine responsiveness. For future investigations, we should also focus on the fact that for ER + endocrine therapy-resistant disease, conventional chemotherapy may not be adequate treatment. We should therefore use the neoadjuvant setting to address two key issues: the development of more effective mechanism-based treatments for endocrine therapy-resistant disease; and the identification of ER + breast cancers that can be managed without chemotherapy.

\section{ACKNOWLEDGEMENTS}

Dr Ellis is supported in this work by Grants R01 CA095614, U01 CA114722 and P30 CA91842. We thank Susan G Komen for the Cure St Louis CRAFT grant and the Breast Cancer Research Foundation grant to the American College of Surgeons Oncology Group (U10CA076001). Dr Ellis reports the following conflict of interests: patents and licensing, bBioclassifier LLC; research grants, Novartis and AstraZenica; and consulting fees and speaking honoraria, Novartis, AstraZenica and Pfizer. Drs Chia and Ma report no conflict of interest.
Berry DA, Cirrincione C, Henderson IC, Citron ML, Budman DR, Goldstein LJ, Martino S, Perez EA, Muss HB, Norton L, Hudis C, Winer EP (2006) Estrogen-receptor status and outcomes of modern chemotherapy for patients with node-positive breast cancer. JAMA 295: 1658-1667

Buchholz TA, Hill BS, Tucker SL, Frye DK, Kuerer HM, Buzdar AU, McNeese MD, Singletary SE, Ueno NT, Pusztai L, Valero V, Hortobagyi GN (2001) Factors predictive of outcome in patients with breast cancer refractory to neoadjuvant chemotherapy. Cancer J 7: 413-420

Cataliotti L, Buzdar AU, Noguchi S, Bines J, Takatsuka Y, Petrakova K, Dube P, de Oliveira CT (2006) Comparison of anastrozole versus tamoxifen as preoperative therapy in postmenopausal women with hormone receptor-positive breast cancer: the Pre-Operative 'Arimidex' Compared to Tamoxifen (PROACT) trial. Cancer 106: 2095-2103

Chakrabarti J, Kenny FS, Syed BM, Robertson JF, Blamey RW, Cheung KL (2010) A randomised trial of mastectomy only versus tamoxifen for 
treating elderly patients with operable primary breast cancer - final results at 20-year follow-up. Crit Rev Oncol Hematol (in press)

Crowder RJ, Phommaly C, Tao Y, Hoog J, Luo J, Perou CM, Parker JS, Miller MA, Huntsman DG, Lin L, Snider J, Davies SR, Olson Jr JA, Watson MA, Saporita A, Weber JD, Ellis MJ (2009) PIK3CA and PIK3CB inhibition produce synthetic lethality when combined with estrogen deprivation in estrogen receptor-positive breast cancer. Cancer Res 69: $3955-3962$

Ding L, Ellis MJ, Li S, Larson DE, Chen K, Wallis JW, Harris CC, McLellan MD, Fulton RS, Fulton LL, Abbott RM, Hoog J, Dooling DJ, Koboldt DC, Schmidt H, Kalicki J, Zhang Q, Chen L, Lin L, Wendl MC, McMichael JF, Magrini VJ, Cook L, McGrath SD, Vickery TL, Appelbaum E, Deschryver K, Davies S, Guintoli T, Crowder R, Tao Y, Snider JE, Smith SM, Dukes AF, Sanderson GE, Pohl CS, Delehaunty KD, Fronick CC, Pape KA, Reed JS, Robinson JS, Hodges JS, Schierding W, Dees ND, Shen D, Locke DP, Wiechert ME, Eldred JM, Peck JB, Oberkfell BJ, Lolofie JT, Du F, Hawkins AE, O'Laughlin MD, Bernard KE, Cunningham M, Elliott G, Mason MD, Thompson Jr DM, Ivanovich JL, Goodfellow PJ, Perou CM, Weinstock GM, Aft R, Watson M, Ley TJ, Wilson RK, Mardis ER (2010) Genome remodelling in a basal-like breast cancer metastasis and xenograft. Nature 464: 999- 1005

Dowsett M, Ebbs SR, Dixon JM, Skene A, Griffith C, Boeddinghaus I, Salter J, Detre S, Hills M, Ashley S, Francis S, Walsh G, Smith IE (2005) Biomarker changes during neoadjuvant anastrozole, tamoxifen, or the combination: influence of hormonal status and HER-2 in breast cancer a study from the IMPACT trialists. J Clin Oncol 23: 2477-2492

Dowsett M, Smith IE, Ebbs SR, Dixon JM, Skene A, A'Hern R, Salter J, Detre S, Hills M, Walsh G (2007) Prognostic value of Ki67 expression after short-term presurgical endocrine therapy for primary breast cancer. J Natl Cancer Inst 99: $167-170$

EBCTCG (2005) Effects of chemotherapy and hormonal therapy for early breast cancer on recurrence and 15-year survival: an overview of the randomised trials. Lancet 365: 1687-1717

Eiermann W, Paepke S, Appfelstaedt J, Llombart-Cussac A, Eremin J, Vinholes J, Mauriac L, Ellis M, Lassus M, Chaudri-Ross HA, Dugan M, Borgs M (2001) Preoperative treatment of postmenopausal breast cancer patients with letrozole: a randomized double-blind multicenter study. Ann Oncol 12: 1527-1532

Ellis MJ, Buzdar A, Unzeitig GW, Esserman L, Leitch AM, Deshryver K, Allred DC, Suman V, Hunt K, Olson JA (2010) ACOSOG Z1031: a randomized phase II trial comparing exemestane, letrozole, and anastrozole in postmenopausal women with clinical stage II/III estrogen receptor-positive breast cancer. J Clin Oncol 28 (Suppl), 7s (abstract LBA513)

Ellis MJ, Coop A, Singh B, Mauriac L, Llombert-Cussac A, Janicke F, Miller WR, Evans DB, Dugan M, Brady C, Quebe-Fehling E, Borgs M (2001) Letrozole is more effective neoadjuvant endocrine therapy than tamoxifen for ErbB-1- and/or ErbB-2-positive, estrogen receptor-positive primary breast cancer: evidence from a phase III randomized trial. J Clin Oncol 19: $3808-3816$

Ellis MJ, Coop A, Singh B, Tao Y, Llombart-Cussac A, Janicke F, Mauriac L, Quebe-Fehling E, Chaudri-Ross HA, Evans DB, Miller WR (2003) Letrozole inhibits tumor proliferation more effectively than tamoxifen independent of HER1/2 expression status. Cancer Res 63: 6523-6531

Ellis MJ, Tao Y, Luo J, A'Hern R, Evans DB, Bhatnagar AS, Chaudri Ross HA, von Kameke A, Miller WR, Smith I, Eiermann W, Dowsett M (2008a) Outcome prediction for estrogen receptor-positive breast cancer based on postneoadjuvant endocrine therapy tumor characteristics. J Natl Cancer Inst 100: $1380-1388$

Ellis MJ, Tao Y, Luo J, Hoog J, Watson M, Allred DC, Bernard PS, Nielsen TO, Perou CM, Olson Jr JA (2008b) A poor prognosis ER and HER2-negative, nonbasal, breast cancer subtype identified through postneoadjuvant endocrine therapy tumor profiling. J Clin Oncol 26 (15s): 502

Ellis MJ, Tao Y, Young O, White S, Proia AD, Murray J, Renshaw L, Faratian D, Thomas J, Dowsett M, Krause A, Evans DB, Miller WR, Dixon JM (2006) Estrogen-independent proliferation is present in estrogen-receptor HER2-positive primary breast cancer after neoadjuvant letrozole. J Clin Oncol 24: 3019-3025

Gazet JC, Ford HT, Gray R, McConkey C, Sutcliffe R, Quilliam J, Makinde V, Lowndes S, Coombes RC (2001) Estrogen-receptor-directed neoadjuvant therapy for breast cancer: results of a randomised trial using formestane and methotrexate, mitozantrone and mitomycin C (MMM) chemotherapy. Ann Oncol 12: 685-691

Hayes DF, Thor AD, Dressler LG, Weaver D, Edgerton S, Cowan D, Broadwater G, Goldstein LJ, Martino S, Ingle JN, Henderson IC,
Norton L, Winer EP, Hudis CA, Ellis MJ, Berry DA (2007) HER2 and response to paclitaxel in node-positive breast cancer. $N$ Engl J Med 357: $1496-1506$

Hind D, Wyld L, Beverley CB, Reed MW (2006) Surgery versus primary endocrine therapy for operable primary breast cancer in elderly women (70 years plus). Cochrane Database Syst Rev 1: CD004272

Horobin JM, Preece PE, Dewar JA, Wood RA, Cuschieri A (1991) Longterm follow-up of elderly patients with locoregional breast cancer treated with tamoxifen only. Br J Surg 78: 213-217

Howell A, Cuzick J, Baum M, Buzdar A, Dowsett M, Forbes JF, Hoctin-Boes G, Houghton J, Locker GY, Tobias JS (2005) Results of the ATAC (Arimidex, Tamoxifen, Alone or in Combination) trial after completion of 5 years' adjuvant treatment for breast cancer. Lancet 365: 60-62

Kaufman B, Mackey JR, Clemens MR, Bapsy PP, Vaid A, Wardley A, Tjulandin S, Jahn M, Lehle M, Feyereislova A, Revil C, Jones A (2009) Trastuzumab plus anastrozole versus anastrozole alone for the treatment of postmenopausal women with human epidermal growth factor receptor 2-positive, hormone receptor-positive metastatic breast cancer: results from the randomized phase III TAnDEM study. I Clin Oncol 27: $5529-5537$

Marcom PK, Isaacs C, Harris L, Wong ZW, Kommarreddy A, Novielli N, Mann G, Tao Y, Ellis MJ (2007) The combination of letrozole and trastuzumab as first or second-line biological therapy produces durable responses in a subset of HER2 positive and ER positive advanced breast cancers. Breast Cancer Res Treat 102: 43-49

Miller WR, Larionov A, Renshaw L, Anderson TJ, Walker JR, Krause A, Sing T, Evans DB, Dixon JM (2009) Gene expression profiles differentiating between breast cancers clinically responsive or resistant to letrozole. J Clin Oncol 27: 1382-1387

Mlineritsch B, Tausch C, Singer C, Luschin-Ebengreuth G, Jakesz R, Ploner F, Stierer M, Melbinger E, Menzel C, Urbania A, Fridrik M, Steger G, Wohlmuth P, Gnant M, Greil R (2008) Exemestane as primary systemic treatment for hormone receptor positive post-menopausal breast cancer patients: a phase II trial of the Austrian Breast and Colorectal Cancer Study Group (ABCSG-17). Breast Cancer Res Treat 112: $203-213$

Mustacchi G, Ceccherini R, Milani S, Pluchinotta A, De Matteis A, Maiorino L, Farris A, Scanni A, Sasso F (2003) Tamoxifen alone versus adjuvant tamoxifen for operable breast cancer of the elderly: long-term results of the phase III randomized controlled multicenter GRETA trial. Ann Oncol 14: 414-420

Olson Jr JA, Budd GT, Carey LA, Harris LA, Esserman LJ, Fleming GF, Marcom PK, Leight Jr GS, Giuntoli T, Commean P, Bae K, Luo J, Ellis MJ (2009) Improved surgical outcomes for breast cancer patients receiving neoadjuvant aromatase inhibitor therapy: results from a multicenter phase II trial. J Am Coll Surg 208: 906-914 (discussion 915-6)

Paik S, Shak S, Tang G, Kim C, Baker J, Cronin M, Baehner FL, Walker MG, Watson D, Park T, Hiller W, Fisher ER, Wickerham DL, Bryant J, Wolmark N (2004) A multigene assay to predict recurrence of tamoxifentreated, node-negative breast cancer. $N$ Engl J Med 351: 2817-2826

Parker JS, Mullins M, Cheang MC, Leung S, Voduc D, Vickery T, Davies S, Fauron C, He X, Hu Z, Quackenbush JF, Stijleman IJ, Palazzo J, Marron JS, Nobel AB, Mardis E, Nielsen TO, Ellis MJ, Perou CM, Bernard PS (2009) Supervised risk predictor of breast cancer based on intrinsic subtypes. J Clin Oncol 27: 1160-1167

Polychronis A, Sinnett HD, Hadjiminas D, Singhal H, Mansi JL, Shivapatham D, Shousha S, Jiang J, Peston D, Barrett N, Vigushin D, Morrison K, Beresford E, Ali S, Slade MJ, Coombes RC (2005) Preoperative gefitinib versus gefitinib and anastrozole in postmenopausal patients with oestrogen-receptor positive and epidermalgrowth-factor-receptor-positive primary breast cancer: a double-blind placebo-controlled phase II randomised trial. Lancet Oncol 6: 383-391

Preece PE, Wood RAB, Mackie CR, Cuschieri A (1982) Tamoxifen as initial sole treatment of localized breast-cancer in elderly women - a Pilot study. Br Med J 284: 869-870

Semiglazov VF, Semiglazov VV, Dashyan GA, Ziltsova EK, Ivanov VG, Bozhok AA, Melnikova OA, Paltuev RM, Kletzel A, Berstein LM (2007) Phase 2 randomized trial of primary endocrine therapy versus chemotherapy in postmenopausal patients with estrogen receptorpositive breast cancer. Cancer 110: 244-254

Seo JH, Kim YH, Kim JS (2009) Meta-analysis of pre-operative aromatase inhibitor versus tamoxifen in postmenopausal woman with hormone receptor-positive breast cancer. Cancer Chemother Pharmacol 63: 261 - 266 Smith IE, Dowsett M, Ebbs SR, Dixon JM, Skene A, Blohmer JU, Ashley SE, Francis S, Boeddinghaus I, Walsh G (2005) Neoadjuvant treatment of 
postmenopausal breast cancer with anastrozole, tamoxifen, or both in combination: the Immediate Preoperative Anastrozole, Tamoxifen, or Combined with Tamoxifen (IMPACT) multicenter double-blind randomized trial. J Clin Oncol 23: 5108-5116

Smith IE, Walsh G, Skene A, Llombart A, Mayordomo JI, Detre S, Salter J, Clark E, Magill P, Dowsett M (2007) A phase II placebo-controlled trial of neoadjuvant anastrozole alone or with gefitinib in early breast cancer. J Clin Oncol 25: 3816-3822

Symmans WF, Peintinger F, Hatzis C, Rajan R, Kuerer H, Valero V, Assad L, Poniecka A, Hennessy B, Green M, Buzdar AU, Singletary SE, Hortobagyi GN, Pusztai L (2007) Measurement of residual breast cancer burden to predict survival after neoadjuvant chemotherapy. J Clin Oncol 25: 4414-4422

Thurlimann B, Keshaviah A, Coates AS, Mouridsen H, Mauriac L, Forbes JF, Paridaens R, Castiglione-Gertsch M, Gelber RD, Rabaglio M, Smith I, Wardley A, Price KN, Goldhirsch A (2005) A comparison of letrozole and

tamoxifen in postmenopausal women with early breast cancer. $\mathrm{N} \mathrm{Engl} \mathrm{J}$ Med 353: $2747-2757$

Torrisi R, Bagnardi V, Pruneri G, Ghisini R, Bottiglieri L, Magni E, Veronesi P, D’Alessandro C, Luini A, Dellapasqua S, Viale G, Goldhirsch A, Colleoni M (2007) Antitumour and biological effects of letrozole and $\mathrm{GnRH}$ analogue as primary therapy in premenopausal women with ER and PgR positive locally advanced operable breast cancer. $\mathrm{Br}$ J Cancer 97: $802-808$

van de Vijver MJ, He YD, van't Veer LJ, Dai H, Hart AA, Voskuil DW, Schreiber GJ, Peterse JL, Roberts C, Marton MJ, Parrish M, Atsma D, Witteveen A, Glas A, Delahaye L, van der Velde T, Bartelink H, Rodenhuis S, Rutgers ET, Friend SH, Bernards R (2002) A gene-expression signature as a predictor of survival in breast cancer. N Engl J Med 347: 1999-2009

Willsher PC, Robertson JFR, Jackson L, AlHilaly M, Blamey RW (1997) Investigation of primary tamoxifen therapy for elderly patients with operable breast cancer. Breast 6: 150-154 